\title{
Peran Notaris Dalam Pendirian Koperasi Setelah Diberlakukannya Online Single Submission
}

\author{
I Gusti Ngurah Wira Prabawa1, Dewa Gde Rudy²
}

${ }^{1}$ Fakultas Hukum Universitas Udayana, E-mail: wiraprabawa@gmail.com

2Fakultas Hukum Universitas Udayana, E-mail: dewarudy1959@gmail.com

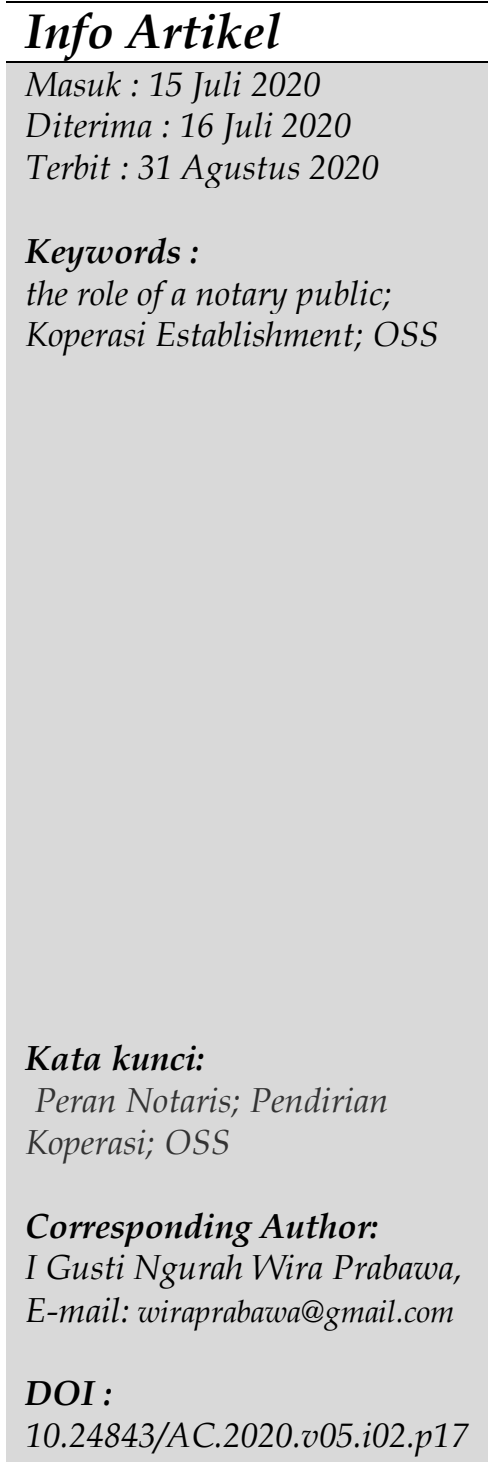

Info Artikel

Keywords :

the role of a notary public

Koperasi Establishment; OSS

Kata kunci:

Peran Notaris; Pendirian

uthor:

I Gusti Ngurah Wira Prabawa

DOI :

$10.24843 / A C .2020 .005 .102 . p 17$

\begin{abstract}
As a public official, Notary has the authority in making authentic deeds. Koperasi is a business entity which is a populist economic movement and is based on the principle of kinship. To obtain status as a legal entity, Koperasi must have a Koperasi Establishment Deed which is drawn up before a Notaris Pembuat Akta Koperasi, which then must obtain approval of the Koperasi Establishment Deed thru the Ministry of Law and Human Rights. Since the promulgation of PP No. 24 year 2018, the business licensing process in Indonesia will be carried out electronically and the businessmen will obtain an NIB as the identity of the business. The problem that arises from this research is how the role of the notary in the establishment of Koperasi is after the implementation of OSS. This research is a normative legal research using the concept approach. The role of the Notary after the enactment of the OSS related to the establishment of the Koperasi is that it will help in providing counseling related to Koperasi and make a deed of establishment of the Koperasi. After the establishment deed is done, then the Notary will apply for legalization of the Koperasi establishment deed through AHU Online, because without the legalization from Ministry of Law and Human Rights, the Koperasi, cannot access the OSS to take process the business licensing.
\end{abstract}

\section{Abstrak}

Sebagai pejabat umum, Notaris memiliki kewenangan untuk pembuatan akta otentik. Koperasi merupakan badan usaha yang merupakan gerakan ekonomi kerakyatan dan didasarkan atas asas kekeluargaan. Sebuah Koperasi agar bisa mendapatkan status sebagai badan hukum, maka harus memiliki Akta Pendirian Koperasi yang dibuat dihadapan Notaris Pembuat Akta Koperasi, yang kemudian harus mendapatkan pengesahan atas Akta Pendirian Koperasi tersebut oleh Kementrian Hukum dan HAM. Sejak diundangkannya PP No. 24 Thn. 2018, maka pengurusan perizinan ber-usaha di Indonesia akan dilaksanakan secara elektronik dan pelaku usaha akan mendapatkan NIB sebagai identitas dari pelaku usaha. Permasalahan yang timbul dari penelitian ini ialah Bagaimanakah peran notaris dalam pendirian koperasi setelah diberlakukannya sistem OSS. Penelitian ini merupaan penelitian hukum normatif dengan menggunakan pendakatan konsep. Peran Notaris setelah berlakunya OSS terkait dengan pendirian Koperasi ialah akan membantu dalam memberikan penyuluhan terkait perkoperasian 
dan membuat akta pendirian koperasi. Setelah adanya akta pendirian, maka Notaris akan melakukan pendaftaran pengesahan akta pendirian Koperasi melalui AHU Online, karena tanpa pengesahan tersebut, pelaku usaha yang dalam hal ini adalah Koperasi tidak dapat mengakses OSS untuk mengurus perizinan usaha.

\section{Pendahuluan}

Seiring berkembangnya jaman dan semakin beragamnya kebutuhan manusia, maka semakin penting adanya kepastian hukum, sehingga jasa di bidang profesi hukum semakin diperlukan pula. Notaris ialah profesi hukum yang banyak dibutuhkan masyarakat.

UU No. 30 Thn. 2004 Tentang Jabatan Notaris sebagaimana yang telah diubah dengan UU No. 2 Thn. 2014 Tetang Perubahan Atas Undang-Undang Nomor 30 Tahun 2004 Tentang Jabatan Notaris (selanjutnya disebut "UUJN") Pasal 1 angka 1 merumuskan "Notaris adalah pejabat umum yang berwenang untuk membuat akta otentik dan kewenangan lainnya sebagaimana dimaksud dalam Undang-Undang ini". Rumusan atas aturan tersebut memperlihatkan kewenangan dari Notaris ialah sebagai pembuat akta otentik. Terkait kepemilikan atas alat bukti sempurna, maka dalam kehidupan saat ini akta otentik memiliki arti yang sangat penting. KUH Perdata Pasal 1870 merumuskan "bagi para pihak yang berkepentingan beserta para ahli warisnya ataupun bagi orang-orang yang mendapatkan hak dari mereka, suatu akta otentik memberikan suatu bukti yang sempurna tentang apa yang termuat di dalamnya". ${ }^{1} \mathrm{KUH}$ Perdata Pasal 1868 merumuskan "suatu akta otentik ialah suatu akta yang dibuat dalam bentuk yang ditentukan undang-undang oleh atau dihadapan pejabat umum yang berwenang untuk itu di tempat akta itu". Dari ketentuan KUH Perdata Pasal 1870 dan 1868, bisa dikatakan bahwa akta otentik adalah akta yang dibuat dihadapan pejabat umum yang berwenang serta dapat memberikan kekuatan pembuktian yang sempurna, dan UUJN Pasal 15 merumuskan bahwa Notaris memiliki wewenang dalam pembuatan akta otentik.

Di Indonesia dikenal beberapa jenis badan usaha, yang UD, CV, Firma, PT dan Koperasi. Bila dibanding jenis badan usaha yang lain, badan usaha koperasi memiliki cara bekerja, serta interaksi internal maupun eksternal yang khusus dan berbeda. Koperasi ialah badan usaha yang memiliki status berbadan hukum. Badan hukum merupakan perkumpulan orang (organisasi) yang bisa melaksanakan perbuatan dan melaksanakan hubungan hukum, sebagai subyek hukum, memiliki hak serta kewajiban, harta kekayaan sendiri dan dapat menggugat ataupun digugat dihadapan pengadilan. ${ }^{2}$

Secara etimologis, kata Koperasi awal mulanya berasal dari kata Cum dan Aperari yang artinya "dengan bekerjasama", yangmana kedua kata berbahasa Latin tersebut di adopsi

1 Erik, M., Triyanto dan Sesung, R. (2018). Karakteristik Akta Otentik Pada Akta Risalah Lelang. Jurnal Jatiswara, 33(2), 1-20. DOI: 10.29303/jatiswara.v33i2.168.

2 Santosa, A.A.G.D.H. (2019). Perbedaan Badan Hukum Publik dan Badan Hukum Privat. Jurnal Komunikasi Hukum (JKH) Universitas Pendidikan Ganesha. 5(2), 152-166. DOI: 10.23887/jkh.v5i2.18468. 
ke dalam bahasa Inggris sehingga menjadi Co dan Operation, sehingga menjadi Cooperative yang artinya "beroperasi bersama-sama". ${ }^{3}$ UU No. 25 Thn. 1992 Tentang Perkoperasian (selanjutnya disebut "UU Perkoperasian") dalam Pasal 1 angka 1 merumuskan "Koperasi adalah badan usaha yang beranggotakan orang-seorang atau badan hukum Koperasi dengan melandaskan kegiatannya berdasarkan prinsip Koperasi sekaligus sebagai gerakan ekonomi rakyat yang berdasar atas asas kekeluargaan." Margono Djojohadijoesomo berpendapat bahwa "koperasi ialah perkumpulan manusia seorang-seorang yang dengan sukanya sendiri hendak bekerja sama untuk memajukan ekonominya". ${ }^{4}$ Pendapat lain diungkapkan oleh Mohammat Hatta yang berpendapat "koperasi adalah usaha bersama untuk memperbaiki nasib penghidupan ekonomi berdasarkan tolong-menolong". ${ }^{5}$

Koperasi memberi jaminan terhadap tiap-tiap individu untuk bisa terlepas dari adanya pengangguran, ketidakadilan, jerat utang, ketidaksetaraan, tidak efisiennya penggunaan modal sosial dan keuangan serta penurunan produktifitas. ${ }^{6}$

Jenis Koperasi terdiri dari Koperasi Jasa, Koperasi Produsen, Koperasi Konsumen, Koperasi Simpan Pinjam dan Koperasi Pemasaran. Koperasi Simpan Pinjam merupakan koperasi yang salah satu tugasnya ialah melaksanakan kegiatan simpan meminjam yang melayani anggotanya. Koperasi Konsumen merupakan jenis koperasi yang kegiatan usahanya melakukan jual beli barang konsumsi, dan anggotanya terdiri dari para konsumen. Koperasi produsen merupakan jenis koperasi yang kegiatan usahanya melakukan pengadaan pengadaan bahan bakuserta merupakan penolong bagi anggotanya, dimana anggota dari jenis koperasi ini ialah para pengusaha kecil. Koperasi pemasaran ialah jenis koperasi yang kegiatan usahanya ialah melakukan penjualan produk/jasa koperasi maupun anggotanya. Koperasi Jasa ialah jenis koperasi yang melakukan usaha pelayanan jasa non simpan pinjam yang diperlukan non anggota maupun anggotanya. ${ }^{7}$ Ketentuan terkait pendirian Koperasi diatur dalam UU Perkoperasian.

Koperasi ialah salah satu pelaku bisnis tentunya perlu adanya kepastian hukum, terutamanya terkait berkas-berkas menyangkut keberadaan serta legalitas dari Koperasi tersebut. ${ }^{8}$ Terkait pendirian suatu Koperasi telah diatur dalam UU Perkoperasian.

3 Wirama, A.P. (2009). Larangan Praktek Monopoli dan Persaingan Usaha Tidak Sehat Pengecualian-Terhadap Badan Usaha Koperasi. Jurnal Hukum \& Pembangunan, 39(1), 74-101. DOI: 10.21143/jhp.vol39.no1.198.

4 Itang. (2016). Badan Usaha Koperasi dan Badan Usaha Non Koperasi (Studi Komparatif). Jurnal Ekonomi Keuangan dan Bisnis Islam, 7(1), 53-76. DOI: 10.32678/ijei.v7i1.35.

5 Pachta, W.A., Bachtiar, M.R., \& Benemay, N.M. (2018). Hukum Koperasi Indonesia: Pemahaman, Regulasi, dan Modal Usaha. Jakarta: Prenadamedia Group. h. 19.

6 Suroto. (2011). Keadilan Distributif Koperasi. Juenal Maksipreneur. 1(1), 21-37. DOI: 10.30588/jmp.v1i1.62.

7 Priliandani, N.M.I., Juniariani, N.M.R., dan Mariyatni, N.P.S. (2018). Pengaruh Ukuran Koperasi, Jenis Koperasi Serta Pengalaman Kepengurusan Manajemen Terhadap Kualitas Sistem Pengendalian Intern Pada Koperasi di Kabupaten Tabanan. Jurnal Aplikasi Akuntansi. 3(1), 141-178. DOI: 10.29303/jaa.v3i1.37.

8 Ratangin, M.G. (2017). Pergeseran Kekuatan Akta Autentik Serta Kewenangan Notaris Dalam Pembuatan Akta Pendirian Koperasi (Pasca Putusan Mahkamah Konstitusi No. 28/PUUXI/2013). Jurnal Lex Renaissance. 1(2), 114-130. DOI: 10.20885/jlr.vol2.iss1.art8. 
Berdasarkan UU Perkoperasian diatur bahwa pendirian atas Koperasi dilaksanakan dengan akta pendirian, dimana dalam akta tersebut berisikan Anggaran Dasar atas Koperasi tersebut dan harus memiliki kedudukan yang berada di wilayah NKRI. Agar mendapatkan status badan hukum, maka akta pendirian Koperasi wajib memperoleh pengesahan dari Pemerintah.

Presiden Indonesia tgl. 21 Juni 2018 telah menandatangani Peraturan Pemerintah (PP) No. 24 Thn. 2018 tentang Pelayanan Perizinan Berusaha Terintegrasi Secara Elektronik (selanjutnya disebut "PP OSS"). PP OSS tersebut merupakan suatu sistem pelayanan perizinan yang menggunakan sistem secara online, dimana dengan adanya sistem online ini diharapkan akan mampu mencegah peluang terjadinya penyalahgunaan wewenang untuk para pelaku usaha dengan pejabat berwenang yang bisa menimbulkan kerugian. ${ }^{9}$ Sebagai suatu sistem, Online Single Submission (OSS) yang dimanfaatkan oleh pemerintah telah diintegerasikan dengan seluruh pelayanan perizinan berusaha yang dilaksanakan dengan cara elektronik demi mendorong standarasisasi dan menjadikan sistem birokrasi perizinan baik itu di tingkat daerah ataupun tingkat pusat akan menjadi lebih mudah, cepat serta menjadi lebih terintegrasi. Namun dalam peraturan tersebut, tidak diatur terkait peran dan batasan tanggung jawab dari seorang notaris dalam hal pendirian koperasi.

Atas dasar pemaparan yang telah diuraikan sebelumnya, terlihat tidak diaturnya peranan ataupun batasan tanggung jawab seorang notaris dalam hal mendirikan koperasi, sehingga penulis tertarik untuk menulis jurnal berjudul "Peran Notaris dalam Pendirian Koperasi Setelah Diberlakukannya Online Single Submission". Berlandaskan pada latar belakang masalah tersebut, sehingga dapat ditarik suatu permasalahan terkait bagaimanakah peran notaris dalam pendirian koperasi setelah diberlakukannya sistem OSS?

Penulisan ini memiliki tujuan untuk mengetahui peran notaris dalam pendirian koperasi setelah diberlakukannya sistem OSS. Penulisan ini merupakan buah pemikiran serta penelitian asli dari penulis, sehingga penilisan ini memiliki orisinalitas yang memadai untuk dijadikan sebuah jurnal ilmiah.

\section{Metode Penelitian}

Penelitian ini tergolong jenis penelitian hukum normatif. Sri Mamuji dan Soerjono Soekanto berpendapat "Penelitian hukum normatif adalah penelitian hukum yang dilakukan dengan cara meneliti bahan pustaka atau data sekunder belaka". ${ }^{10}$ Bahanbahan hukum penelitian ini bersumber peraturan perundang-undangan terkait, doktrin yang relevan serta literature-literatur hukum yang memiliki keterkitan terhadap topik

9 Putri. RR.A.M. (2020). Pelayanan Izin Lingkungan Dalam Mendukung Iklim Usaha yang Kondusif Terkait dengan Sistem Pelayanan Izin Berusaha Terintegrasi (OSS). Jurist-Diction Law Journal. 3(1), 287-302. DOI: 10.20473/jd.v3i1.17637.

10 Barus, Z. (2013). Analisis Filosofis Tentang Peta Konseptual Penelitian Hukum Normatif dan Penelitian Hukum Sosiologis. Jurnal Dinamika Hukum. 13(2), 307-318. DOI: 10.20884/1.jdh.2013.13.2.212. 
pembahasan dari penelitian ini. Penelitian ini adalah penelitian Deskriptif Analitis, yaitu "memaparkan apa adanya tentang suatu peristiwa hukum atau kondisi hukum". ${ }^{11}$

Pendekatan merupakan suatu cara pandang dari penelitian untuk memberi kejelasan terhadap substansi atas suatu karya ilmiah dengan menentukan spectrum ruang bahasan. Adapun pendekatan yang dipergunakan menganalisa permasalahan yang ada di penelitian ini ialah pendekatan konsep. Pendekatan konseptual ini diawali dengan doktrin-doktrin serta pandangan-pandangan ilmu hukum yang berkembang di dalamnya. Dengan mendalami pandangan-pandangan serta doktrin-doktrin yang ada pada ilmu hukum, akan bisa menemukan ide serta dapat memunculkan pengertian hukum, konsep hukum maupun asas hukum yang berkaitan dengan permasalahan yang tengah dibahas. ${ }^{12}$

Penelitian ini mempergunakan sumber bahan primer yang berupa literature, karya ilmiah serta jurnal terdahulu, dan bahan hukum sekunder berupa peraturan perundangundangan yang berhubungan dengan penilitian ini, yang terdiri dari UU Jabatan Notaris, UU Perkoperasian dan peraturan perundang-undangan lainnya yang bertalian dengan permasalahan yang sedang dibahas.

\section{Hasil Dan Pembahasan}

\section{Peran Notaris dalam Pendirian Koperasi Setelah diberlakukannya Sistem OSS}

UUJN pada Pasal 1 angka 1 disebutkan "Notaris adalah pejabat umum yang berwenang untuk membuat akta autentik dan memiliki kewenangannya lainnya sebagaimana dimaksud dalam Undang-undang ini atau berdasarkan undang-undang lainnya." Perumusan dimuat pada UUJN Pasal 1 angka 1 tersebut ialah suatu peraturan pelaksanaan atas KUH Perdata Pasal 1868. Sebagai pejabat umum, Notaris melaksanakan tugas publik yang memberikan pelayanan kepada masyarakat umum dalam hal hukum perdata yang dapat kedudukannya sama dengan pejabat negara. Setelah diangkat oleh Menteri, seorang Notaris bisa menjalankan tugasnya secara independent, bebas serta bebas dari pengaruh badan eksekutif dan badan lainnya, sehingga dapat bertindak secara netral. ${ }^{13}$ Dalam UUJN telah diatur bahwa kewenangan yang dimiliki dari seorang Notaris ialah untuk membuat akta otentik yang bertalian terhadap hal-hal yang berhubungan dengan perbuatan, perjanjian serta kewenangan lainnya yang diatur melalui undang-undang dan/atau yang diperlukan oleh yang memiliki kepentingan untuk dapat dituangkan kedalam akta otentik, selama akta yang hendak dibuat tidak dikecualikan, ditugaskan kepada pejabat atau orang lain yang telah diatur oleh undang-undang. Bagi masyarakat yang perlu suatu alat pembuktian, maka akta otentik itu sangatlah penting, baik itu dalam hal kepentingan usaha maupun dalam hal kepentingan pribadi.

11 Diantha, I.M.P. (2019). Metodologi Penelitian Hukum Normatif dalam Justifikasi Teori Hukum. Jakarta: Prenadamedia Group. h. 152.

12 Salim HS, H., \& Nurbani, E.S. (2014). Penerapan Teori Hukum pada Penelitian Tesis dan Disertasi. Jakarta: Rajawali Pers. h. 19.

13 Nurmayanti, R., \& Khisni, A. (2017). Peran dan Tanggung Jawab Notaris dalam Pelaksanaan Pembuatan Akta Koperasi. Jurnal Akta. 4(4), 609-622. DOI: 10.30659/akta.4.4.609\%20-\%20622. 
Koperasi merupakan badan usaha yang berbadan hukum perlu memiliki kepastian hukum. Dalam pendirian Koperasi, diperlukan adanya Akta Pendirian Koperasi. Dasar hukum atas petunjuk pelaksanaan dari pembentukan, pengesahan serta perubahan anggaran dasar atas Koperasi telah diatur di Peraturan Menteri Negara Koperasi dan Usaha Kecil dan Menengah Republik Indonesia No: 01/Per/M.KUKM/I/2006 tentang Petunjuk Pelaksanaan Pembentukan, Pengesahan Akta Pendirian dan Perubahan Anggaran Dasar Koperasi (selanjutnya disebut "PERMENKOP NO. 1/06"). Pasal 1 angka 1 PERMENKOP NO. 1/06 merumuskan bahwa "Akta Pendirian Koperasi adalah surat keterangan tentang pendirian sesuatu koperasi yang berisi pernyataan dari para kuasa pendiri yang ditunjuk dan diberi kuasa dalam suatu rapat pembentukan koperasi untuk menandatangani anggaran dasar pada saat pembentukan koperasi." Anggaran Dasar Koperasi ialah aturan dasar yang dibuat dalam bentuk tertulis, yang paling tidak berisikan daftar nama dari pendiri koperasi, nama serta kedudukan, jenis koperasi yang hendak didirikan, maksud tujuan serta bidang usaha yang hendak di jalankan, ketentuan mengenai keanggotaan, rapat anggota, pengelolaan, permodalan, jangka waktu berdirinya, pembagian sisa hasil usaha, serta ketentuan terkait saksi.

PERMENKOP NO. 1/06 dalam Pasal 1 angka 3 serta angka 4 merumuskan bahwa pejabat yang berwenang serta ditunjuk oleh Menteri Negara Koperasi dan Usaha Kecil dan Menengah Republik Indonesia ialah Notaris yang telah ditetapkan sebagai Notaris Pembuat Akta Koperasi. Sebagai pejabat umum, Notaris akan berfungsi dalam pembuatan akta-akta autentik yang berkaitan dengan keberadaan dari pada Koperasi yang merupakan badan usaha berbadan hukum. Notaris yang ditunjuk diharapkan akan lebih banyak membantu pembuatan akta-akta yang berhubungan dengan bidang perkoperasian, serta diharapkan pula bisa membantu Koperasi dalam memberikan pertimbangan hukum serta nasihat hukum. ${ }^{14}$

Notaris agar bisa diangkat sebagai Notaris Pembuatan Akta Koperasi oleh Menteri Negara Koperasi dan Usaha Kecil dan Menengah Republik Indonesia, maka Notaris yang bersangkutan wajib untuk mengikuti pembekalan di bidang perkoperasian terlebih dahulu, yang nantinya akan dibuktikan dengan sertipikat yang ditandatangani oleh Menteri Koperasi dan UKM. Pembekalan terhadap Notaris tersebut tidak lain berkaitan dengan nilai-nilai serta prinsip-prinsip Koperasi serta terkait dengan proses pembentukan, penggabungan dan tentang pembubaran Koperasi. Apabila telah memperoleh sertipikat yang berisikan bukti keikutsertaan Notaris tersebut dalam pembekalan di bidang perkoperasian, maka Notaris tersebut wajib melaporkan kepada Kepala Dinas/Instansi yang membidangi koperasi ditingkat kabupaten/kota dengan melampirkan SK pengangkatan Notaris, sertifikat bukti mengikuti pembekalan bidang perkoperasian, serta mencantumkan alamat kantor, contoh paraf, cap stempel Notaris dan contoh tanda tangan dari Notaris yang bersangkutan. Setelah melakukan melakukan pelaporan, maka Notaris tersebut akan menerima tanda terima permohonan dan Kepala Dinas/Instansi yang membidangi Koperasi tingkat Kabupaten/Kota tersebut akan menyampaikan dokumen pendaftaran tersebut kepada Menteri. Setelah tahapan tersebut terlaksana, Menteri akan menetapkan Notaris yang bersangkutan sebagai Pejabat Pembuat Akta Koperasi (PPAK) melalui SK. Menteri yang langsung akan disampaikan kepada Notaris yang bersangkutan dengan tembusan kepada Menteri Hukum dan Hak Asasi Manusia dan Kepala Dinas/Instansi yang membidangi

14 Op.cit., Ratangin, M.G. h. 90. 
Koperasi tingkat Kabupaten/Kota dimana lokasi kedudukan dari Notaris yang Bersangkutan. Setelah Notaris yang bersangkutan menerima surat Keputusan sebagai PPAK, maka Notaris tersebut wajib segera melapor ke instansi Koperasi di daerah kerjanya, dan Notaris yang bersangkutan resmi sebagai PPAK di daerah kerja Kabupaten/Kota. ${ }^{15}$

Pasal 4 Peraturan Menteri Negara Koperasi dan Usaha Kecil dan Menengah Republik Indonesia No. 10/Per/M.KUKM/IX/2015 tentang Kelembagaan Koperasi mengatur bahwa dalam proses pendirian Koperasi, para Pendiri Koperasi wajib untuk melangsungkan rapat persiapan pembentukan koperasi, dimana dalam rapat persiapan tersebut akan membicarakan hal-hal yang berkenaan terhadap perencanaan dalam pendirian koperasi, nama koperasi, rancangan anggaran koperasi, rencana jenis kegiatan usaha yang akan dijalankan, pemilihan pengurus, pemilihan pengawas, dan nominal simpanan pokok serta simpanan wajib yang akan menjadi modal awal dari Koperasi tersebut. Persiapan atas rapat persiapan tersebut dilakukan oleh penyuluh koperasi terlebih dahulu. Penyuluh koperasi tersebut dapat berasal dari instansi pemerintah ataupun non pemerintah, dimana saat rapat tersebut, Notaris pembuat akta koperasi dapat hadir dan mencatat inti dari hasil pembahasan yang telah disepakati didalam rapat yang nantinya akan dituangkan pada akta pendirian koperasi yang bersangkutan.

Koperasi yang telah memiliki Akta Pendirian harus melakukan permohonan pengesahan untuk mendapatkan status badan hukum. Berdasarkan isi ketentuan dari Peraturan Menteri Hukum dan Hak Asasi Manusia No. 14 Thn. 2019 tentang Pengesahan Koperasi (selanjutnya disebut dengan "PERMENKUMHAM 14/19"), permohonan pengesahan Anggaran Koperasi tersebut diajukan oleh Pemohon yang dalam hal ini dilakukan oleh Notaris selaku kuasa dari pemohon kepada Menteri yang menyelenggarakan urusan pemerintahan di bidang hukum melalui Direktur Jendral Administrasi Hukum Umum. Permohonan tersebut diajukan dalam Sistem Administrasi Badan Hukum (SABH), dimana sebelum diajukannya pengesahan, pemohon harus melakukan pemesanan nama Koperasi terlebih dahulu. Pengesahan / pengajuan nama koperasi ini bertujuan untuk memberikan identitas resmi yang spesifik bagi tiap Koperasi yang berbadan hukum, dan untuk menghindari adanya penyalahgunaan nama Koperasi. PERMENKUMHAM 14/19 mengatur bahwa pengajuan nama Koperasi tersebut diajukan mengisi format pengajuan nama Koperasi pada $\mathrm{SABH}$, yang dalam pengajuan tersebut setidaknya berisikan nama Koperasi yang hendak dipesan serta jenis Koperasinya.

Nama Koperasi yang hendak dipesan setidaknya harus terdiri dari 3 kata setelah frasa Koperasi dan jenis koperasi. Apabila nama tersebut telah memenuhi persyaratan dan disetujui, maka Menteri akan diberikan secara elektronik, yang mana persetujuan tersebut berlaku 30 hari yang terhitung sejak diberikannya persetujuan nama Koperasi tersebut.

Permohonan pengesahan atas akta pendirian koperasi harus diajukan selambatlambatnya 60 hari terhitung dari waktu penandatanganan akta pendirian. Permohonan pengesahan tersebut dilaksanakan secara elektronik dengan mengisi format pengesahan

15 Widyaningrum, I., (2010). Peranan Notaris Sebagai Pejabat Umum Didalam Pembuatan Akta Pendirian Badan Usaha Koperasi. Universitas Diponegoro. 
akta pendirian serta melengkapi dokumen pendukung yang berupa pernyataan dari pihak pemohon terkait dengan kelengkapan atas dokumen untuk pendirian koperasi yang dibuat secara elektronik. Pemohon yang dalam hal ini dikuasakan kepada Notaris juga diharuskan untuk mengunggah akta pendirian Koperasi tersebut serta berita acara Koperasi dalam SABH. Apabila permohonan diterima, maka menteri akan menerbitkan Keputusan Menteri yang berkaitan dengan pengesahan akta pendirian koperasi tersebut melalui elektronik kemudian Notaris Pembuat Akta Koperasi dapat melaksanakan pencetakan terhadap Keputusan Menteri tersebut dengan menggunakan kertas berukuran F4/Folio berwarna putih dengan berat 80 gram. Pengesahan atas Koperasi tersebut akan diumumkan dalam Berita Negara Republik Indonesia.

Proses yang dilaksanakan berikutnya ialah melakukan pengurusan Nomor Pokok Wajib Pajak (NPWP) atas Koperasi tersebut. Bila NPWP telah terbit, maka pendiri dapat melanjutkan dengan proses registrasi OSS (Online Single Submission) untuk bisa memperoleh Nomor Induk Berusaha (NIB). OSS merupakan suatu sistem yang diterbitkan oleh Pemerintah yang dalam hal ini Lembaga OSS untuk dan atas nama menteri, pimpinan lembaga, gubernur, atau bupati/wali kota kepada pelaku Pelaku Usaha secara elektronik dan terintegrasi guna mempermudah proses pengurusan Izin Usaha maupun Izin Komersial atau Izin Operasional suatu badan usaha maupun usaha perorangan. ${ }^{16}$ Manfaat lain yang akan didapatkan oleh pelaku usaha dengan adanya sistem OSS ialah penyimpanan data perizinan data perizinan usaha dalam satu identitas berusaha (NIB).

UUD 1945 Pasal 18 ayat (2) merumuskan bahwa pemerintah tingkat daerah provinsi, kabupaten maupun kota mempunyai kewenangan atas otonomi daerahnya dan tugas pembantuan. Sebagaimana diatur dalam UU No. 23 Thn. 2014 ialah pemerintah daerah mempunyai wewenang dalam hal mengeluarkan izin, dimana kewenangan tersebut bukanlah kewenangan yang bersifat utuh, tetapi konkuren, yang masih perlu untuk memperhatikan dan berkoordinasi dengan pemerintah pusat. Dalam hal perizinan, pemerintah telah berusaha untuk memperbaiki dan memperbaharui sistem perizinan di Indonesia, yang ditunjukkan dengan berlakunya PP No. 24 Thn. 2018 tetang Pelayanan Perizinan Berusaha Terintegrasi Secara Elektronik.

Izin dalam melakukan suatu usaha terdapat berbagai macam, baik itu berupa Izin usaha maupun Izin operasinal. Pasal 1 angka 8 PP OSS merumuskan "Izin Usaha adalah izin yang diterbitkan oleh Lembaga OS untuk dan atas nama menteri, pimpinan lembaga, gubernur, atau bupati/wali kota setelah pelaku usaha melakukan Pendaftaran dan untuk memulai usaha dan/atau kegiatan sampai sebelum pelaksanaan komersial atau operasional dengan memenuhi persyaratan dan/atau Komitmen". Komitmen yang dimaksud dalam hal ini ialah pernyataan dari pada pelaku usaha dalam pemenuhan segala persyaratan yang diperlukan dalam Izin Usaha maupun dalam Izin Operasinal.

Upaya yang dilakukan oleh pemerintah dalam mengendalikan tingkah laku dari masyarakatnya ialah dengan adanya Izin, dimana Izin merupakan salah satu bentuk dari pemenuhan atas asas keabsahan/asas legalitas. Asas legalitas merupakan suatu

16 Widya, E., Prananingtyas, P., dan Ispriyarso, B. (2019). Pelaksanaan Penerbitan Nomor Induk Berusaha Melalui Sistem Online Submission (Studi Pendirian Perseroan Terbatas di Kota Semarang). Notarius, Jurnal Studi Kenotariatan. 12(1), 231-252. DOI: 10.14710/nts.v12i1.26901. 
dasar legitimasi atas tindakan dari pemerintah dan merupakan suatu jaminan perlindungan atas hak-hak rakyat. Asas legalitas akan mendukung adanya persamaan perlakuan serta kepastian hukum. ${ }^{17}$ Terdapat 3 hal yang merupakan unsur dari asas keabsahan, yaitu unsur wewenang, dimana dalam suatu wewenang setidaknya terdapat 3 komponen, yang meliputi pengaruh, dasar hukum serta konformitas hukum. ${ }^{18}$

Persyaratan yang harus dilengkapi sebelum melengkapi OSS ialah adanya NIK penanggung jawab badan usaha maupun usaha perorangan, telah diselesaikannya pengesahan badan usaha oleh Kementrian Hukum dan HAM dengan sistem AHU Online (bagi badan usaha berupa PT, badan usaha yang didirikan oleh yayasan, koperasi, CV, firma, maupun persekutuan perdata) sebelum mengakses OSS, serta bagi pelaku usaha dengan badan usaha yang berupa perum, perumda, maupun badan hukum lainnya yang kepemilikannya oleh negara, maka badan layanan umum atau lembaga penyiaran harus mempersiapkan dasar hukum atas pendirian badan usaha tersebut. 19

Nomor Induk Usaha (NIB) akan diperloeh setelah proses registrasi dalam OSS berhasil dilakukan. NIB ialah identitas daripada pelaku usaha yang diterbitkan oleh lembaga OSS. NIB ini wajib untuk dimiliki oleh para pelaku usaha baik usaha perseorangan ataupun badan usaha, dan NIB ini wajib pula dimiliki oleh pelaku usaha yang baru ataupun yang beroperasi sebelum adanya operasionalisasi dari OSS, karena NIB juga merupakan Tanda Daftar Perusahaan (TDP), Angka Pengenal Impor (bila kegiatan usaha yang dijalankan adalah kegiatan usaha impor) serta merupakan akses kepabean (bila kegiatan usaha yang dilakukan ialah ekspor dan/atau impor).

\section{Kesimpulan}

Saat Proses pendirian koperasi, Notaris yang dalam hal ini ialah Notaris Pembuat Akta Koperasi berperan untuk memberikan penyuluhan kepada para pendiri. Kemudian atas dasar kuasa pendiri, mengajukan permohonan persetujuan nama Koperasi. Setelah mendapat persetujuan, para pendiri membuat Akta Pendirian Koperasi dihadapan Notaris Pembuat Akta Koperasi. Setelah Akta Pendirian Koperasi selesai, maka dalam waktu kurang dari 60 hari, Notaris yang dalam hal ini selaku kuasa dari para pendiri akan mengajukan pengesahan atas akta pendirian tersebut kepada Kementrian Hukum dan HAM melalui AHU Online. Tanpa diselesaikannya proses pengesahan oleh Notaris melalui AHU Online, maka pelaku usaha tidak bisa mengakses OSS dan mengurus perizinan berusaha.

17 Suhayati, M. (2018). Permasalahan Perizinan Berusaha Terintegrasi Secara Elektronik (Online Submission System). Retrieved from http://berkas.dpr.go.id/puslit/files/info_singkat/Info\%20Singkat-X-23-I-P3DI-Desember2018-241.pdf, diakses 1 Maret 2020.

18 Arrum, D.A. (2019). Kepastian Hukum Dalam Perizinan Berusaha Terintegrasi Secara Elektronik (Online Single Submission) di Indonesia. Jurist-Diction Law Journal. 2(5), 16311654. DOI: $10.20473 /$ jd.v2i5.14222.

19 Indonesia.go.id Portal Informasi Indonesia. Online Single Submission: Perizinan Berusaha Melalui OSS. Available from https://www.indonesia.go.id/layanan/investasi/sosial/perizinan-berusaha-melalui-oss.

(Diakses 29 Februari 2020) 
Dengan adanya sistem OSS, maka harus lebih sering untuk diadakannya sosialisasi dan memberikan pemahaman terkait Online System Submision baik itu kepada kalangan masyarakat, gerakan koperasi maupun kepada Notaris Pembuat Akta Koperasi, sehingga bisa mendapatkan pemahaman dalam pengurusan Izin Usaha maupun Izin Komersial atau Operasional suatu usaha, salah satunya dalam bidang usaha Koperasi. Adapun sosialisasi tersebut dapat dilaksanakan baik itu melalui media elektronik, media masa, media sosial, maupun melalui bimbingan teknis.

Selain diperlukannya sosialisasi, perlu juga adanya kepastian fasilitas berupa perangkat dan koneksi internet guna menjamin kelancaran dari system tersebut.

\section{Daftar Pustaka / Daftar Referensi}

\section{Buku}

Pachta, W.A., Bachtiar, M.R., \& Benemay, N.M. (2018). Hukum Koperasi Indonesia: Pemahaman, Regulasi, dan Modal Usaha. Jakarta: Prenadamedia Group.

Diantha, I.M.P. (2019). Metodologi Penelitian Hukum Normatif dalam Justifikasi Teori Hukum. Jakarta: Prenadamedia Group. h. 152.

Salim HS, H., \& Nurbani, E.S. (2014). Penerapan Teori Hukum pada Penelitian Tesis dan Disertasi. Jakarta: Rajawali Pers.

\section{Jurnal}

Arrum, D.A. (2019). Kepastian Hukum Dalam Perizinan Berusaha Terintegrasi Secara Elektronik (Online Single Submission) di Indonesia. Jurist-Diction Law Journal. 2(5), 1631-1654. DOI: $10.20473 /$ jd.v2i5.14222.

Barus, Z. (2013). Analisis Filosofis Tentang Peta Konseptual Penelitian Hukum Normatif dan Penelitian Hukum Sosiologis. Jurnal Dinamika Hukum.13(2), 307-318. DOI: 10.20884/1.jdh.2013.13.2.212

Erik, M., Triyanto dan Sesung, R. (2018). Karakteristik Akta Otentik Pada Akta Risalah Lelang. Jurnal Jatiswara, 33(2), 1-20. DOI: 10.29303/jatiswara.v33i2.168.

Itang. (2016). Badan Usaha Koperasi dan Badan Usaha Non Koperasi (Studi Komparatif). Jurnal Ekonomi Keuangan dan Bisnis Islam, 7(1), 53-76. DOI: 10.32678/ijei.v7i1.35.

Nurmayanti, R., \& Khisni, A. (2017). Peran dan Tanggung Jawab Notaris dalam Pelaksanaan Pembuatan Akta Koperasi. Jurnal Akta. 4(4), 609-622. DOI: 10.30659/akta.4.4.609\%20-\%20622

Priliandani, N.M.I., Juniariani, N.M.R., dan Mariyatni, N.P.S. (2018). Pengaruh Ukuran Koperasi, Jenis Koperasi Serta Pengalaman Kepengurusan Manajemen Terhadap Kualitas Sistem Pengendalian Intern Pada Koperasi di Kabupaten Tabanan. Jurnal Aplikasi Akuntansi. 3(1), 141-178. DOI: 10.29303/jaa.v3i1.37. 
Putri. RR.A.M. (2020). Pelayanan Izin Lingkungan Dalam Mendukung Iklim Usaha yang Kondusif Terkait dengan Sistem Pelayanan Izin Berusaha Terintegrasi (OSS). Jurist-Diction Law Journal. 3(1), 287-302. DOI: 10.20473/jd.v3i1.17637.

Ratangin, M.G. (2017). Pergeseran Kekuatan Akta Autentik Serta Kewenangan Notaris Dalam Pembuatan Akta Pendirian Koperasi (Pasca Putusan Mahkamah Konstitusi No. 28/PUU-XI/2013). Jurnal Lex Renaissance. 1(2), 114-130. DOI: 10.20885/jlr.vol2.iss1.art8.

Santosa, A.A.G.D.H. (2019). Perbedaan Badan Hukum Publik dan Badan Hukum Privat. Jurnal Komunikasi Hukum (JKH) Universitas Pendidikan Ganesha. 5(2), 152-166. DOI: $10.23887 / j k h . v 5 i 2.18468$.

Suroto. (2011). Keadilan Distributif Koperasi. Juenal Maksipreneur. 1(1), 21-37. DOI: 10.30588/jmp.v1i1.62.

Widya, E., Prananingtyas, P., dan Ispriyarso, B. (2019). Pelaksanaan Penerbitan Nomor Induk Berusaha Melalui Sistem Online Submission (Studi Pendirian Perseroan Terbatas di Kota Semarang). Notarius, Jurnal Studi Kenotariatan. 12(1), 231-252. DOI: $10.14710 /$ nts.v12i1.26901.

Widyaningrum, I., (2010). Peranan Notaris Sebagai Pejabat Umum Didalam Pembuatan Akta Pendirian Badan Usaha Koperasi. Universitas Diponegoro.

Wirama, A.P. (2009). Larangan Praktek Monopoli dan Persaingan Usaha Tidak Sehat Pengecualian-Terhadap Badan Usaha Koperasi. Jurnal Hukum \& Pembangunan, 39(1), 74-101. DOI: 10.21143/jhp.vol39.no1.198.

\section{Peraturan Perundang-undangan}

Undang-Undang Dasar Negara Republik Indonesia Tahun 1945.

Kitab Undang-Undang Hukum Perdata, 2009, Burgelijk Wetboek, diterjemahkan oleh Prof. R. Subekti, SH dan R. Tjitrosudibio, Cetakan ke Empatpuluh, Pradnya Paramita, Jakarta.

Republik Indonesia, Undang-Undang Nomor 25 Tahun 1992 Tentang Perkoperasian (Lembaran Negara Republik Indonesia Tahun 1992 Nomor 116, Tambahan Lembaran Negara Republik Indonesia Nomor 3502).

Republik Indonesia, Undang-Undang Nomor 30 Tahun 2004 Tentang Jabatan Notaris (Lembaran Negara Republik Indonesia Tahun 2004 Nomor 117, Tambahan Lembaran Negara Republik Indonesia Nomor 4432).

Republik Indonesia, Undang-Undang Nomor 23 Tahun 2014 Tentang Pemerintahan Daerah (Lembaran Negara Republik Indonesia Tahun 2014 Nomor 244, Tambahan Lembaran Negara Republik Indonesia Nomor 5587) 
Republik Indonesia, Peraturan Pemerintah Nomor 24 Tahun 2018 Tentang Pelayanan Perizinan Berusaha Terintegrasi Secara Elektronik (Lembaran Negara Republik Indonesia Tahun 2018 Nomor 90, Tambahan Lembaran Negara Republik Indonesia Nomor 6215).

Republik Indonesia, Peraturan Menteri Koperasi dan UKM Nomor 01/Per/M.KUKM/I/2006 Tentang Petunjuk Pelaksanaan Pembentukan, Pengesahan Akta Pendirian dan Perubahan Anggaran Dasar Koperasi.

Republik Indonesia, Peraturan Menteri Koperasi dan UKM Nomor 10/Per/M.KUKM/IX/2015 Tentang Kelembagaan Koperasi (Berita Negara Republik Indonesia Tahun 2015 Nomor 1489).

Republik Indonesia, Peraturan Menteri Hukum dan HAM Nomor 14 Tahun 2019 Tentang Pengesahan Koperasi.

\section{Laman}

Indonesia.go.id Portal Informasi Indonesia. Online Single Submission: Perizinan Berusaha Melalui OSS. Available from https://www.indonesia.go.id/layanan/investasi/sosial/perizinan-berusahamelalui-oss. (Diakses 29 Februari 2020).

Suhayati, M. (2018). Permasalahan Perizinan Berusaha Terintegrasi Secara Elektronik (Online Submission System). Retrieved from http://berkas.dpr.go.id/puslit/files/info_singkat/Info\%20Singkat-X-23-I-P3DIDesember-2018-241.pdf, (diakses 1 Maret 2020). 